\title{
Atividade Antimicrobiana de Filmes À Base de Amido Adicionados de Óleos Essenciais
}

Janaina Mayumi Honma (I), Sandriane Pizato (II), Denize Marques da Silva (I), Gustavo Graciano Fonseca (I), William Renzo CortezVega (I)

(I) UFGD - UNIVERSIADE FEDERAL DA GRANDE DOURADOS (Rua João Rosa Góes, 1761 Vila Progresso. Caixa Postal 322 - CEP: 79.825-070), (II) FURG - UNIVERSIDADE FEDERAL DO FIO GRANDE (Campus Carreiros: Av. Itália km 8 Bairro Carreiros )

\section{Resumo}

A crescente preocupação com a qualidade microbiológica dos alimentos tem aumentado o interesse por filmes antimicrobianos. A embalagem antimicrobiana é um tipo promissor de embalagem ativa que apresenta substância antimicrobiana incorporada ou imobilizada no material da embalagem que é capaz de eliminar ou inibir micro-organismos deterioradores e/ou patogênicos. O objetivo deste trabalho foi desenvolver e avaliar a atividade antimicrobiana de filmes à base de amido de batata com adição de óleo essencial de orégano (Origanum vulgare), cravo-daÍndia (Syzygium aromaticum) e inula (Inula helenium L.). Os filmes foram elaborados conforme a técnica de casting. A concentração de óleos essenciais utilizada foi de $1 \%$. Foi avaliado o efeito antimicrobiano, da área da inibição do crescimento contra Salmonella typhimurium, Bacillus cereus, Staphylococcus coagulase positiva, pelo método de difusão em disco. Com base nos dados obtidos do diâmetro de inibição nos filmes com óleo essencial de cravo, oregano e inula, uma análise da variância foi realizada para avaliar diferenças entre os filmes e entre cepa bacteriana testada. Os filmes de amido sem a presença de óleos essenciais não apresentaram halo de inibição, e também não houve o crescimento dos micro-organismos avaliados sobre os filmes. Os filmes de amido com óleo essencial de inula apresentaram propriedade inibitórias apenas contra Staphylococcus coagulase positiva e Bacillus cereus, com pequenos halos

\footnotetext{
Referência:

Janaina Mayumi Honma, Sandriane Pizato, Denize Marques da Silva, Gustavo Graciano Fonseca, William Renzo Cortez-Vega. Atividade Antimicrobiana de Filmes À Base de Amido Adicionados de Óleos Essenciais. In: Anais do 12º Congresso Latinoamericano de Microbiologia e Higiene de Alimentos - MICROAL 2014 [= Blucher Food Science Proceedings, num.1, vol.1]. São Paulo: Editora Blucher, 2014. DOI 10.5151/foodsci-microal-332
} 
de inibição. Houve diferença significativa entre os 4 tipos de filmes adicionados de óleo essenciais. Os filmes com óleo essencial de orégano apresentaram inibição, sendo que em torno do filme e até sobre ele não houve multiplicação dos micro-organismos, diferente do comportamento do filme controle (sem óleo essencial). Segundo os resultados, os óleos essenciais de orégano e cravo podem liberar compostos ativos para prevenir e controlar o crescimento de patógenos em alimentos. Com isso podemos concluir que os óleos essenciais de cravo e orégano na preparação de filmes de amido, podem ser considerados antimicrobianos.

Palavras-Chave: filmes, antimicrobianos, qualidade Agência de Fomento: 